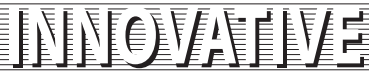

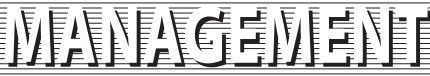

\section{SMART CITY NARRATIVE \\ IN INDONESIA: COMPARING \\ POLICY DOCUMENTS \\ IN FOUR CITIES}

\section{Arif Budy Pratama}

Lecturer in Public Administration, Universitas Tidar, Indonesia

Address: 39 Jl. Kapten S Parman,

56116 Magelang, Indonesia.

E-mail: arifpratama@untidar.ac.id

\begin{abstract}
This paper aims to investigate the narrative of smart city policy in four Indonesian cities. Yogyakarta City, Surabaya City, Magelang City, and Madiun City were chosen as the locus of this study since these cities were winners of the Indonesian Smart City Index 2015.

The author compares their medium-term development planning documents using analysis of policy narrative approach which reconstructs the stories that actors tell about policy issues written in the official policy document. This study endeavours to analyse how these cities engage with smart city policy and initiative from a comparative-based study.

Based on the content analysis as a research method, it can be concluded that these cities conceptualise the smart city program in different ways since there is no specific regulation guiding smart city policy in Indonesia. The result of this study also maps the main themes of smart city as stated in their medium-term development planning document. Theoretically, it contributes the discourse of smart city policy studies in a developing country context. Practically, this study suggests a policy implication that cities need to consider as a specific grand design on how local government implement smart city initiative.
\end{abstract}

Keywords: cities; urban studies; urban affairs; urban policy; smart city; smart city policy; policy narrative; analysis of policy narrative; content analysis; comparative study; Indonesia.

Citation: Pratama, A.B. (2018). Smart City Narrative in Indonesia: Comparing Policy Documents in Four Cities. Public Administration Issues, Special Issue II (electronic edition), pp. 65-83 (in English); DOI: 10.17323/1999-5431-2018-0-6-65-83 


\section{Introduction}

Asian cities are at the centre of urban flux causing complexities in their urban affairs (Menon, 2017). In line with the development of technology, smart city is regarded as one of the solutions addressing various urban problems. The smart city diffusion has grown rapidly and become a trending word across the globe. $\mathrm{Nu}$ merous cities in South East Asia including Indonesia have become keen on 'smart' recognition and immediately jumped on the bandwagon to apply this fashion of urban policy. Practitioners, politicians, and public managers eagerly shout smart cities as a jargon in their day-to-day administration.

Studies on smart city in Indonesia have mushroomed in the last five years as have efforts to address complexities in managing urban affairs. Recent literature in Indonesian smart city research are highly focused on techno-managerial venues with a special emphasis on sustainability issues. Numerous studies have tried to uncover the technology features in the implementation of a smart city program such as Suakanto et al. (2013); Sutanta, Aditya, and Astrini (2016); Sasono et al. (2016); Susanti et al. (2016); Wiseli, Tanusetiawan, and Purnomo (2017). Other studies focused on smart environment and sustainability (Rahmat, Syadiah \& Subur, 2016; Rusadi et al., 2016; Rachmawati, 2017) and co-creation and smart city governance (Mayangsari \& Novani, 2015). Also in the disability and human right discourse Suryotrisongko, Kusuma and Ginardi (2017) investigated how smart city design deals with disability issues.

Even though they offer a wide range of explanations in the Indonesian context, limited studies have been done to address smart city policy-related issues. None of the studies emphasizes how policymakers understand and conceptualise smart city in their official policy documents. The trajectory on policy-related research on Indonesian smart city is needed to enrich the Indonesian smart city discourse. In the other facade, understanding issues, topics, themes, and problems are fundamental parts in the public policy process (Parsons, 1995; Howlett, 2011). Deeper understanding can be attained by defining the issues in the most appropriate context. Thus, well-defined policy agenda in the policy process is very beneficial to obtain quality decision making. Understanding urban development strategic policy and agenda which is narrated in the regional development planning document will provide valuable insights on how city governments engage with smart city initiative.

This study will close the knowledge gap on smart city research by focusing on smart city strategic policy as a platform of urban development. The purpose of this study is to investigate the definition and conceptualisation of smart city from the policy narrative perspective. Therefore, this article will tackle the following two questions: 1) How do the winners of the smart city contest in Indonesia conceptualise the smart city concept in their policy documents? 2) What smart city themes have frequently emerged in their policy documents? These research questions are very important because they allow us to understand the conceptualisation of smart city from a policy-maker perspective.

This article starts with a theoretical review of the smart city concept and smart city research in Indonesia. Then, an investigation into smart city's definition 
and conceptualisation, based on their strategic policy documents, is conducted. Further, I discuss a comparison analysis to understand how these cities engage with the smart city program. In the last section, the author concludes and comes up with policy implications based on the findings and discussion.

\section{Smart City: Understanding the Concept}

The smart city concept originated from the word smart growth which was mainly used in urban planning activities (Harrison \& Donnelly, 2011). Then, it was widely used by Information Technology Corporations such as Siemens (2004), CISCO (2005), IBM (2009), and Alcatel (2012) in relation to building information systems supporting urban infrastructures. These forms can be telecommunication, transportation, energy and waste management, and other public service provisions. This smart city concept further develops into an ideal city that uses technology to improve the quality of life and satisfy citizens' needs.

In practice, smart city may be mentioned in many terminologies such as digital city (Rezende et al., 2014), intelligent city (Komninos, 2006; Mulay et al., 2011), city information (Piro et al., 2014), and ubiquitous city (Anthopoulos \& Fitsilis, 2010). These variations are parts of different meanings by which cities interpret smart city policies. The simple way to interpret the smart city concept is by chopping the phrase into single words. Smart city contains two words: smart and city. The practical terms of city can be understood as a place where people live but more modern than a village or town, and with more complicated problems as well. From the residential point of view, the city is not just a place to work but is a liveable place. While smart, can be defined as clever, competent, ingenious, resourceful and proficient according to the Indonesian Dictionary. Generally-speaking, smart city is a liveable urban place that offers smart and competent services to its inhabitants.

Being aware that smart city is a complicated concept and comes from many fields (Albino, Berardi \& Dangelico, 2015), a common definition is hard to achieved (Nam \& Pardo, 2011; Gil-Garcia, Pardo \& Nam, 2015). Either in academic scenes or practical venues, there is no consensus to define what is meant by smart city and how it should be implemented (Gil-Garcia, Pardo \& Nam, 2015), albeit the phrase 'smart city' has been widely used in urban governance (Chourabi et al., 2011; Nam \& Pardo, 2011; Alejandro et al., 2014; Neirotti et al., 2014). As an emerging-multidiscipline concept, smart city is still in progress and applied in different nomenclatures and contexts. Being "smart" means that multiple stakeholders aim for sustainable solutions adopting digitalization (Öberg, Graham \& Hennelly, 2017, p. 470). The use of digitalization means applying technology advancement which supports smart city implementation. This concept is in the same boat with Caragliu, Del Bo and Nijkamp (2011) who argued that smart city deals with investments in social capital, economic growth and a high quality of life. A weight of foundation on technological dimension is also claimed by other scholars. Kim, Ramos and Mohammed (2017) related the smart city implementation with the internet of things (IoT) which refers to the use of technology of IoT in smart city development. The use of IoT corroborates with Paroutis, Bennett and Heracleous 
(2014) who exposed the strategic views on smart city technology in the case of IBM smart city.

Other disciplines see different views on smart city definitions, for instance, in the area of urban and regional planning study, Angelidou (2014) argues that smart cities are urban settlements that seek to utilize strategic information technology landscapes to achieve the prosperity, effectiveness and competition levels of cities. She pinpoints the key themes of agglomeration of urban development along with an urban development model based on the utilization of human, collective, and technology. This perspective focuses smart city on landscape and settlement issues for city habitants.

A different point of view comes from the public administration perspective which argues that the notion of society, efficiency, and governance should be integrated into smart city implementation. Anthopoulos and Reddick (2016) noted smart city as the ability of cities to integrate public sector innovations not always, although mostly, from information technology to improve living standards in the context of society, economics, mobility and governance. In this sense, public-sector innovation is in the lead to improve quality of life. The smart city implementation should be complemented by collaboration which involves many actors and stakeholders in urban life. Snow, Håkonsson and Obel (2016, p. 92) state that "A (a) smart city can be understood as a community in which citizens, business firms, knowledge institutions, and municipal agencies collaborate with one another to achieve systems integration and efficiency, citizen engagement, and a continually improving quality of life". This definition underlines the important aspect of collaboration among smart city actors to achieve the quality of life in the urban area. Similarly, Öberg, Graham and Hennelly (2017) have also noted that smart city is a new way of organizing characterized by shifting production and consumption from global to local, manufacturing from competitive to collaborative, and changing business processes from a shareholder to a multiplestakeholder perspective.

From the various concepts and definitions above, we can draw some key issues and principles shaping smart city concepts such as the use of information technology, physical infrastructure, social capital, business world, and the governance aspect to go to a habitable city in an innovative way. The core concept can be clustered into three main features. First, the use of technology especially information and communication technology. Second, the availability of infrastructure and network as well as management in supporting the smart city program. Third, the smart city initiative is intended to provide quality public services and address societal problems in the urban area. In the practical setting, Giffinger (2007) offers a multidimensional component of smart city consisting of smart economy, smart people, smart governance, smart mobility, smart environment, and smart living.

\section{Situating Smart City Research in Indonesia}

The smart city concept has stolen high attention from both academics and practitioners in Indonesia. Several studies have already been conducted from various angles. Some of the most notable studies were conducted in the ma- 
jor cities in Indonesia that are perceived as smart cities. These studies can be grouped into three streams and have shaped the body of literature in Indonesian smart city research.

The first stream is called smart technology research, which mainly focused on the technological issues and a sensor-based application. Suakanto et al. (2013) proposed monitoring the application to help summarize the current condition of Bandung city. Using a dashboard as a prototype, it provides more accurate information about what happened in the entire city. In the same way, Susanti et al. (2016) developed an indicator for residential density in Indonesia to support decision making on smart population. The sensor-based application has also been developed by Sutanta, Aditya, and Astrini (2016) who employ Geographical Information System (GIS) to provide topographic maps and land parcel maps. In the public transportation issue, Sasono et al. (2016) studied the necessity of a smart subway system to tackle the congestion problem based on smart technology.

The second stream pays strong attention to sustainability issues. Thus, this kind of research is called smart environment. Some of the studies were conducted in relation to the Sustainable Development Goals. Rachmawati (2017) studied qualitative research, especially comparative analysis between Bandung city and other smart cities best practices from abroad as the benchmark. She argues that a smart city initiative should consider a smart environment program since it implies positive transformation of the urban development. Other studies also highlight the importance of an environmental perspective on implementing smart city such as Rahmat, Syadiah, and Subur (2016) who scrutinize pollution load in coastal areas as well as the modelling of dynamics in water areas as a source of information and data to enhance public awareness on water pollution. Further, Rusadi et al. (2016) stressed the point that the local authorities should have a commitment to provide green open space if they want to implement smart city.

The last research stream has centred its discussion on the governance and human aspect. Mayangsari and Novani (2015) researched the academic development of multi-stakeholder co-creation analysis in smart city management based on the perspective of service science. Using a literature review as their research method, they argue that the smart city initiative cannot be well-implemented without co-creation from various stakeholders. In line with this argument, the smart city initiative should consider the involvement of the community at large as well as inter-governmental coordination and cooperation (Tarigan et al., 2016). Other studies have tried to understand the smart city implementation through games. Wiseli, Tanusetiawan, and Purnomo (2017) conducted an experiment on gamification on smart city and claim that games can be used to improve the idea of smart city initiatives. One more interesting research targets disability-friendly regarding smart city design. A literature review and comparison study by Suryotrisongko, Kusuma and Ginardi (2017) reached the conclusion that smart city designers need to consider Four-Hospitality, which consists of accessible, safety, problem solving, and flexible as the standard benchmark assessment of smart city design. 


\section{Smart City as a Socio-technological Effort}

The smart city initiative should not be perceived as a technological issue alone, but a complex process of institutional change (Meijer \& Bolivar, 2016). Some frameworks explaining smart city have been proposed by scholars such as Chourabi et al. (2011) who offer smart city as an integrative framework, Harrison and Donnelly (2011) with their urban system, and Nam and Pardo (2011) who argue smart cities as multi-dimensional entities consisting of technology, people, and communities. Of the three models, the multi-dimensional perspective by Nam and Pardo (ibid.) is likely become the ideal choice as an analytical framework for understanding smart city policies in research loci. This model is similar to what Meijer and Bolivar (2016) called smart urban governance focused on technology, human resource, and governance. The institutional perspective by Nam and Pardo (2011) is very similar to the governance focus from Meijer and Bolivar (2016), while the human resource is equal to the human factor by Nam and Pardo (2011).

The multi-dimensional perspectives of technology, human, and institutional factors are rationally located in the interconnection and interdependence themes to support smart city policy implementation. In addition, the model is drawn from the practical experience of cities that are considered successful in implementing the concept of smart city. The principle of integration of these three factors is the synergy of infrastructure and technology services, social learning for infrastructure strengthening, and governance for the improvement of institutional quality and community participation.

The transformation of smart city initiatives requires interaction between technological components, the social context of urban citizens, and institutional policy. In other words, the concept of smart city does not live in a vacuum. The political domains of a smart city made up of local leaders, local parliaments, citizens, and interest groups will influence the smart city policies. In addition, the technocratic level of local government bureaucracy also contributes to the implementation process (Alejandro et al., 2014; Dameri, 2013). The political domain shall be considered and synchronized with the public demands and policy setting agenda (Klijn \& Koppenjan, 2012; Wolfe, Jones \& Baumgartner, 2013; Meijer \& Bolivar, 2016).

\section{Data and Method}

\section{City Choice}

One of the smart city assessments in Indonesia is the Indonesia Smart City Indicators or Indikator Kota Cerdas Indonesia (IKCI). This benchmark was initiated by Kompas - a national mass media corporation, Bandung Institute of Technology (ITB), and National Gas Company/Perusahaan Gas Negara (PGN). The IKCI index integrates an internal bureaucracy assessment including both infrastructure and supra-structure and the external-citizens perception as the manifestation of service responses. Thus, it comprehensively measures the smart city performance from both internal and external aspects. IKCI has six categories of assessment using parameters of population, economic, social, and environmental category. 
Table 1

The winners of smart city IKCI 2015

\begin{tabular}{|l|c|}
\hline \multicolumn{1}{|c|}{ Categories } & Winners \\
\hline Population over 1 million people & The city of Surabaya \\
\hline Population of 200.000 to 1 million people & The city of Yogyakarta \\
\hline Population up to 200.000 & The city of Magelang \\
\hline Economic & The city of Magelang \\
\hline Social & The city of Madiun \\
\hline Environment & The city of Surabaya \\
\hline
\end{tabular}

Magelang city, Yogjakarta city, Surabaya city, and Madiun city were chosen as representatives of Indonesia's top achievers in the Indonesia Smart City Indicators 2015. Reading about how they define and conceptualize smart city in the urban development planning will enhance our understanding of the way in which policymakers posit smart city as a foundational element of urban policy implementation. This study also offers an empirical comparison on how they set smart city policies. To do this, the author focuses on the analysis of strategic policy dimensions. The strategic policy on the smart city program becomes very important and influential in terms of understanding the smart city initiative (Chourabi et al., 2011) and firmly leads the implementation phase (Angelidou, 2014; Dameri \& Cocchia, 2013; Renata Paola Dameri, 2013; Paroutis, Bennett, \& Heracleous, 2014).

\section{Document Choice and Criteria}

The dissemination of smart city policy agenda can be formed in many ways such as by law, policy briefs or memos, press releases, features on their website, and social media. However, these variations would generate confusion and difficulties on comparative analysis. A set of criteria is employed to maintain the objectivity and validity of comparative analysis. Ideally, the narrative policy approach should be analyzed from the regulation that specifically regulates the smart city initiative. Unfortunately, there has not been a specific regulation that guides the smart city initiative such as a blueprint, a grand design or a roadmap. For instance, Surabaya City has not legalized its smart city program, but we can find some regulations supporting the realisation of smart city (Suhendra, 2017) such as Mayor Regulation Number 5/2013 on Guidelines for Technology Utilization Information and Communication in Organizing Local government or Mayor Regulation Number 28/2013 on Service Licensing and Non-Licensing by Electronics in Surabaya City.

Thus, the choice of policy document falls into Regional Medium Terms Development Planning Document /Rencana Pembangunan Jangka Menengah Daerah (RPJMD). RPJMD is the foundational strategic policy document in which city governments design the development planning agenda. The decision on picking RPJMD is backed up by four reasons.

Firstly, the RPJMD document is a compulsory document that guides Indonesian local governments to implement local development. This means that all 
the local governments, without exception, should have an RPJMD document as an administrative guidance for the next five years' polity. The procedure of the decision-making process of RPJMD document is standardized to all local governments in Indonesia. Secondly, The RPJMD stretches to five years of implementation. It allows local governments to design and implement their strategic policy in the medium period. Being aware that smart city outcomes cannot be achieved in the relatively short-term period, the medium-term development agenda fits for this study. Thirdly, the RPJMD is legalised into regulation as the manifestation of agreement between the local legislative body and a major/regent/governor as an executive entity. Since the RPJMD is an official directive, it enforces local governments to implement development agenda in accordance with RPJMD. Fourthly, the process of RPJMD is funded by local government budgets which leads to autonomy and internal motives. This condition tends to reflect that the smart city initiative comes from the internal city government, rather than sponsored by external parties such as non-government organizations or corporations.

This study focuses on chapters five and six of the RPJMD ${ }^{1}$ document that declares the vision, mission, aims, target, strategies and policy directions. These chapters reflect the strategic policy layer through which city governments develop action plan for urban development.

\section{Analysis of Policy Narrative}

This study follows the narrative policy analysis tradition which emphasises policy analysis using stories or a narrative approach (Van Eeten, 2007; Roe, 1994; Shanahan, Mcbeth \& Hathaway, 2011; van Eeten, Loucks \& Roe, 2002; Van Eeten \& Roe, 2000). This study utilised the analysis of policy narrative approach which reconstructs the stories that actors tell about policy issues written in the official policy document.

To compare policy texts, this study applied content analysis as a method. In the text analysis paradigm, Carter, Ladrech, Little, \& Tsagkroni (2017) and Will, Benoit, Slava, \& Laver (2011) argued that analytical techniques can be placed into two extremes from qualitative to quantitative in the continuum line. To take advantage and avoid any weaknesses from both continuum, this study posited in the middle range which accommodates qualitative and quantitative modes of analysis. In the qualitative analysis, the researcher analysed RPJMD using semantic analysis and made signposts on the important issues related to the smart city contents. While quantitative analysis is treated to support the qualitative argument. Technically, the author used designation analysis (Krippendorff, 2013) to identify the smart city themes.

The data management is aided by NVivo 11 as a qualitative analysis software to ease the text analysis of the city government policy documents. NVivo contains two cores of apparatuses and includes Nodes to designate the theme of analysis and source where the set of text is stored and organized. Based on the literature re-

\footnotetext{
1 The 4 policy documents are Regional Regulation Number 10/2016: Regional Medium Terms Development Plan 2016-2021 for Surabaya City, Regional Regulation Number 7/2012: Regional Medium Terms Development Plan 2012-2016 for Yogyakarta City, Regional Regulation Number 1/2016: Regional Medium Terms Development Plan 2016-2021 for Magelang City, and Regional Regulation Number 4/2014: Regional Medium Terms Development Plan 2014-2019 for Madiun City.
} 
view on smart city characteristics and its dimensions, seven Nodes were employed to understand how city governments define smart city and interpret this notion in their policy documents. Further, three Nodes were used to identify core themes which occurred in smart city initiatives.

Table 2

Smart City Definition Text Analysis Framework

\begin{tabular}{|c|l|l|}
\hline No. & \multicolumn{1}{|c|}{ Nodes } & \multicolumn{1}{|c|}{ Description } \\
\hline 1 & $\begin{array}{l}\text { Explicit definition } \\
\text { of smart city }\end{array}$ & The document explicitly presents the smart city definition on its text \\
\hline 2 & Smart economy & $\begin{array}{l}\text { The document emphasises smart city as smart economy } \\
\text { (and its indicators) and stressed competitiveness as a keyword }\end{array}$ \\
\hline 3 & Smart people & $\begin{array}{l}\text { The document emphasises smart city as smart people (and its indicators) } \\
\text { and stressed social and human capital as keywords }\end{array}$ \\
\hline 4 & Smart governance & $\begin{array}{l}\text { The document emphasises smart city as smart governance } \\
\text { (and its indicators) and stressed participation as a keyword }\end{array}$ \\
\hline 5 & Smart mobility & $\begin{array}{l}\text { The document emphasises smart city as smart mobility } \\
\text { (and its indicators) and stressed transport and ICT as keywords }\end{array}$ \\
\hline 6 & Smart environment & $\begin{array}{l}\text { The document emphasises smart city as smart environment } \\
\text { (and its indicators) and stressed natural resources as keywords }\end{array}$ \\
\hline 7 & $\begin{array}{l}\text { Smart living } \\
\text { The document emphasises smart city as smart living (and its indicators) } \\
\text { and stressed quality of life as keywords }\end{array}$ \\
\hline
\end{tabular}

Table 3

Themes on Smart city initiative

\begin{tabular}{|c|l|l|}
\hline No. & \multicolumn{1}{|c|}{ Nodes } & \multicolumn{1}{c|}{ Description } \\
\hline 1 & Technological aspect & The document stated technology as the main aspect of smart city initiative \\
\hline 2 & Institutional aspect & The document stated governance as the main aspect of smart city initiative \\
\hline 3 & Human aspect & $\begin{array}{l}\text { The document stated human factor and social capital of people who live } \\
\text { in the city as the main aspect of smart city initiative }\end{array}$ \\
\hline
\end{tabular}

\section{Findings}

\section{Explicit Definition}

Based on the content analysis, only Magelang City explicitly states the notion of a smart city in its policy document. In Magelang city's RPJMD, Smart city is defined as "a city with effective and efficient management to optimise services to its citizens fairly without discrimination with the support of information technology-based communication connectivity in the business world, public service delivery system, community participation mechanism in conveying aspiration, control, and complaints to support regional competitiveness" (RPJMD Kota Magelang, V-1). Further, it also declares a component of smart city in six dimensions: (a) Smart Governance 
indicated by the development of e-governance and community participation in development planning, (b) Smart Infrastructure indicated by the development of an IT network and IT based management information system, (c) Smart Economy indicated by city branding development, entrepreneurship development, e-commerce development, and a creative economy, (d) Smart environment indicated by management of an IT-based environment, IT-based natural resource management and utilization of renewable energy source, (e) Smart people indicated by the education and development of literate human resources and research support and development of the socio-cultural character of the community (f) Smart Living indicated by easy access to education services, easy access to health services, media role development, and easy access to security guarantees. The other three cities do not mention the notion of smart city in their policy documents explicitly.

\section{Interpreting Smart City Conception from the Urban Development Planning Agenda}

To ease the elucidation of smart city translation in their policy documents, the analysis of vision, mission, strategy and policy direction will firstly be presented. Secondly, the comparative analysis of a whole policy document from 4 cities will follow accordingly.

\section{Yogyakarta City}

The first strategic policy layer is a vision statement. Yogyakarta City wants to be a city with quality education, a community with character and inclusive, supported by cultural-based tourism and a centre of services with an environmentally-based economy. From this narrative, it can be interpreted that Yogyakarta City's vision is highly stressed in three dimensions named smart people, smart economy, and smart environment. The second strategic policy layer can be analysed in its mission statement. Yogyakarta City has a mission to achieve smart governance and a smart economy. The mission statement consists of four areas: to achieve good and clean governance, to achieve quality public services, to achieve community empowerment, and to achieve strong regional competitiveness. To operationalise the vision and mission, Yogyakarta City sets the aims of the urban development agenda as a third strategic policy layer. Its aims are to organize a quality government, to improve quality public services, to improve welfare and strengthen regional competitiveness. From this narration, the third strategic policy layer is aimed accomplishing smart governance, smart people, and smart economy. While, the operational level of strategy and policy direction include every aspect in the smart city dimension: smart economy, smart people, smart governance, smart living, smart mobility, and smart environment.

\section{Surabaya City}

Surabaya city has a vision to be a prosperous, character-based, globally-competitive and ecological-based city. Prosperity and global competitiveness can be considered as smart economy achievements, while a character-based city implies smart people attainment and ecology-based city is correspondent with smart envi- 
ronment. This vision is materialized in ten mission statements: (1) to achieve quality community resources (smart people), (2) to empower the community and create the widest opportunity for all (smart people), (3) to maintain security and public order (smart living), (4) to realize an integrated spatial arrangement and attention to urban capacity (smart living), (5) to strengthen the facilities and infrastructure and the environmentally friendly settlements (smart environment), (6) to strengthen local cultural values in society (smart people), (7) to be a hub of trade and services on a national as well as international level (smart mobility), (8) to strengthen good governance implementation (smart governance), (9) to strengthen the competitiveness of local economic enterprises, product innovation and services, and the development of creative industries (smart economy), (10) to achieve integrated city infrastructure and utilities (smart living).

These ten mission statements have already covered six smart city dimensions: smart economy, smart people, smart governance, smart living, smart mobility, and smart environment. All missions have also been translated into the strategy and policy direction contained in six dimensions of smart city. In short, Surabaya City wants to achieve the ultimate goals contained smart economy, smart people and smart environment.

\section{Magelang City}

Magelang city states its vision as a smart and modern service provider based on a prosperous and religious society. This vision clearly calls the notion of smartness as a key point in its policy document which can be treated as a mainstreaming agenda in the effort of urban development. The interpretation of this vision mainly pinpoints smart economy to provide excellent services and to attain smart people, and which is reflected by a religious society. To achieve its vision, Magelang city has five missions. Firstly, to improve the qualified and professional apparatus by optimizing technology as the basic requirement of clean local government and responsiveness. This mission focuses on the direction of smart governance since it relies on good and clean governance and community participation. Secondly, the mission is aimed at developing and maintaining urban facilities as well as basic services of education, health, and trade. These kinds of services will be delivered in more modern and environmentally friendly ways. This narration can be attributed to the smart living and smart environment. Thirdly, Magelang city states its mission to increase the equity of urban infrastructures to support economic development and community welfare. This statement is closely associated with smart living and smart economy. Fourthly, Magelang city wants to develop cultural and local art as the foundation of development and tourism in Magelang city. This narrative entitles Magelang city to be a culturally-based community which can be attributed to the smart people perspective. Lastly, the mission is designated to the foundational element of civil society which notably is going to be the fulfilment of smart people.

\section{Madiun City}

Madiun city declares its vision to be a better and prosperous city. A better city is defined as a solid and harmonic society based on local wisdom and religiosity, whilst prosperous means all community members reach social-economic 
independence. Thus, smart people and smart economy are most suited to be interpreted in its vision. To achieve its vision, Madiun city has four missions. The first mission is envisioned to realise participative development. This statement emphasises the people as the centre of development. The second mission is related to smart governance since it designates to achieve a clean and good governance in the process of governing. The other two are closely directed to smart people and smart economy due to their attribution on public service provision and prosperity to the people. Madiun city operationalises its vision and missions into strategy and policy directions. Although it does not explicitly state it in detail, all dimensions of the smart city initiative had been represented in Madiun city's policy directions.

The comparison of their vision, mission, strategies, and policy direction are presented in Table 4.

Table 4

\section{Comparisons Among the Four Cities ${ }^{\star}$}

\begin{tabular}{|l|l|l|l|l|}
\hline \multicolumn{1}{|c|}{ Policy Layer } & \multicolumn{1}{|c|}{ Yogyakarta } & \multicolumn{1}{|c|}{ Surabaya } & \multicolumn{1}{c|}{ Magelang } & \multicolumn{1}{c|}{ Madiun } \\
\hline Vision & $\begin{array}{l}\text { 3 dimensions } \\
\text { (people, economy, } \\
\text { environment) }\end{array}$ & $\begin{array}{l}\text { 3 dimensions } \\
\text { (people, economy, } \\
\text { environment) }\end{array}$ & $\begin{array}{l}\text { 2 dimensions } \\
\text { (people, economy) }\end{array}$ & $\begin{array}{l}\text { 2 dimensions } \\
\text { (people, economy) }\end{array}$ \\
\hline $\begin{array}{l}\text { Missions } \\
\text { and aims }\end{array}$ & $\begin{array}{l}\text { 2 dimensions } \\
\text { (governance, } \\
\text { economy) }\end{array}$ & $\begin{array}{l}\text { 6 dimensions } \\
\text { (economy, people, } \\
\text { governance, living, } \\
\text { mobility, and } \\
\text { environment) }\end{array}$ & $\begin{array}{l}\text { 5 dimensions } \\
\text { (economy, people, } \\
\text { governance, living, } \\
\text { and environment) }\end{array}$ & $\begin{array}{l}3 \text { dimensions } \\
\text { (governance, } \\
\text { economy, people) }\end{array}$ \\
\hline $\begin{array}{l}\text { Strategies } \\
\text { and Policy } \\
\text { Directions }\end{array}$ & $\begin{array}{l}\text { 6 dimensions } \\
\text { (economy, people, } \\
\text { governance, } \\
\text { living, mobility, } \\
\text { and environment) }\end{array}$ & $\begin{array}{l}\text { 6 dimensions } \\
\text { (economy, people, } \\
\text { governance, living, } \\
\text { mobility, and } \\
\text { environment) }\end{array}$ & $\begin{array}{l}\text { 6 dimensions } \\
\text { (economy, people, } \\
\text { governance, living, } \\
\text { mobility, and } \\
\text { environment) }\end{array}$ & $\begin{array}{l}\text { (economy, people, } \\
\text { governance, living, } \\
\text { mobility, and } \\
\text { environment) }\end{array}$ \\
\hline
\end{tabular}

* Synthesised by Author based on the Giffinger \& Fertner (2007) framework

From the above table, there are various patterns on how cities formulate their urban development plan in the perspective of smart city dimensions. The analysis refers to the hierarchical strategic policy as a guiding program on urban development. Yogyakarta city and Surabaya city are equal in vision statement. Both contain three smart dimensions in the corpus of people, economy, and environment. The other two, Magelang City and Madiun City are in the same boat which reflects two dimensions in their vision statement consisting of smart people and smart economy. Unlike, Yogyakarta City and Surabaya City, Magelang City and Madiun City do not attach an environmental aspect to their vision statement.

The missions and aims section refers to the core activities in order to achieve the vision. In this section, all four cities are in a different state. Surabaya city contains all the smart city dimensions in its mission statement. Yogyakarta city has only two dimensions comprising smart governance and economy, while Madiun city has three dimensions involving smart governance, smart economy, and smart people. The similarities among them can be seen in the strategies and policy directions as 
the operational facade of strategic urban development planning. Smart economy, smart people, smart governance, smart living, smart mobility, and smart environment dimensions emerge in all of the cities. The fact that strategies and policy directions are given more detailed themes of smart city dimensions is understandable since the higher the operational level, the more details there will be.

\section{Core Themes}

Another central attention in the policy narrative analysis is 'what themes have frequently occurred in their official policy document. In this study, a themes framework was drawn and adapted from Nam and Pardo (2011) and Meijer and Bolivar (2016) which consisted of technology, institutional, and a human aspect. From the Matrix Coding Query analysis, four cities experience similar distribution on themes. All of the cities relatively share on average about $24.79 \%$ in human aspect, $65.94 \%$ on institutional aspect, and $9.31 \%$ on technological aspect. In Yogyakarta city, the core development on urban policy planning contains $23.36 \%$ on human aspect, $74.45 \%$ on institutional aspect, and only $2.19 \%$ on technological aspect. Compared to the other three cities, Yogyakarta has the highest content on institutional aspect, yet the smallest number on technological aspect. Surabaya city experiences $20.71 \%$ on human aspect which is the smallest among the four cities, and $61.64 \%$ on the institutional aspect. However, it has the highest content on technological aspect meaning that this city emphasises a technological facet in its urban development in order to implement a smart city program. Lastly, Madiun city and Magelang city are placed in the moderate position since they are in the middle range of the coding measurement in the institutional and technological aspect. On the human aspect, both are first and second place in the human aspect content respectively. Extended data and visualisation can be seen in the appendices.

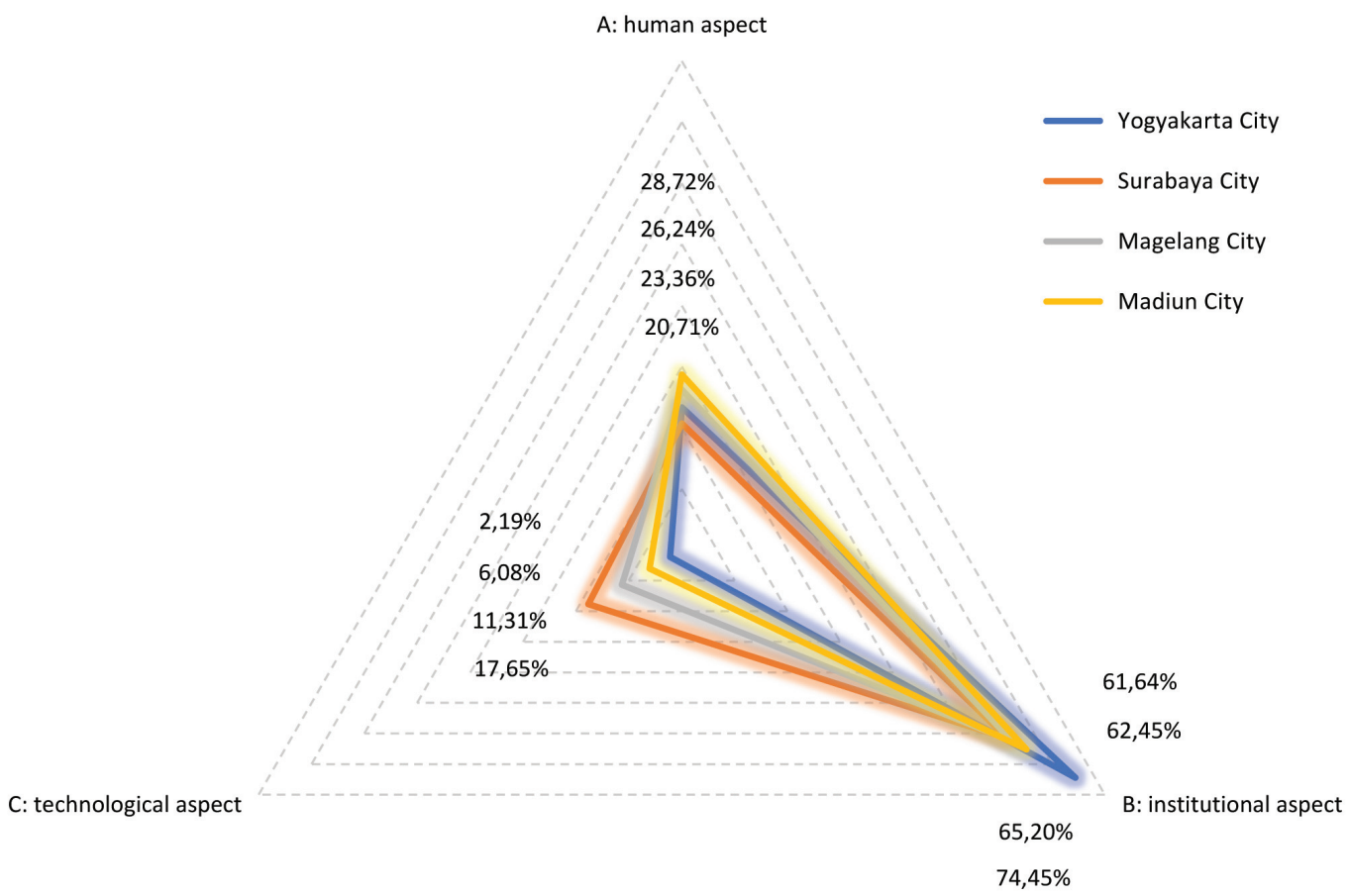




\section{Discussion}

The findings of this study show that cities in the research loci conceptualised smart city differently. Using the smart city dimensions and themes corroborates with the literature, especially the six smart city dimensions (Giffinger, 2007) and smart city core themes (Nam \& Pardo, 2011; Meijer \& Bolivar, 2016), and the result contributes to the discussion of institutional factors in relation to laws and regulations influencing policy implementation. On digital government studies, LunaReyes, Mellouli, \& Bertot (2013) stated that regulation is one of the critical success factors in the implementation. Other studies conducted by Angelidou (2014) and Paroutis et al (2014) have also argued that cities should take into account policies as a core element of smart city development. Instead of challenging this argument, this study advocates that policy and regulation need to be developed as a prerequisite to the smart city initiative.

The finding also shows that some cities have not integrated the political and administrative domain of the smart city initiative into an urban development plan agenda. The gap on political aspect is reflected by the fact that there is lack of clarity on smart city conception stated in the official policy document. Only one city - Magelang city- states clearly what this city means by smart city. This phenomenon leads to an agenda setting deficit since regulation is an important platform of policy agenda (Klijn \& Koppenjan, 2012; Wolfe, Jones \& Baumgartner, 2013).

The investigation into policy review shows that there is no policy document specifically regulating a smart city program within Indonesian local government. Consequently, there is no comprehensive strategic policy that navigates city government on smart city implementation. There were only partial policies linked to the smart city initiative. For instance, Surabaya city has not legalised its smart city program, yet some regulations support the realisation of smart city such as Mayor Regulation Number 5/2013 on Guidelines for Technology Utilisation of Information and Communication in Organizing Local government. Yogyakarta city also regulates the implementation of e-government as a partial policy to support the effort of smart city implementation by Mayor Regulation Number 15 from 2015. The absent of comprehensive strategic policy on smart city initiative will yield a vague implementation by city administration. In addition, it will soon transform as a buzzword, jargon, and media speak with inconsistent meaning. There is also a potential for a vested interest or political benefit which will be counter-productive to the smart city development. Thus, the existence of comprehensive smart city policy is urgently needed in Indonesian local government as the foundational policy document in implementing the smart city initiative in their jurisdiction.

In relation with the survey result of IKCI 2015, the theme reflected in the RPJMD is in accordance with the result of the IKCI survey held in 2015. From the matrix coding query result, Yogyakarta city has the highest frequency in institutional aspect and the lowest content on technology aspect. While Surabaya city is ranked number one in the technological aspect compared to the three others. Lastly, in the human aspect, Madiun city has the highest content 
on attaining smart people which is highly stressed within health and education development. The content on RPJMD and survey results have indicated that official policy influences the way in which city government implements urban development.

\section{Conclusion}

The motivation behind this study is to analyse how recognised smart cities in Indonesia (Yogyakarta city, Surabaya city, Magelang city, and Madiun city) conceptualise a smart city program in their official policy document. Based on a content analysis from their medium-term development planning documents (RPJMD), this study shows that only Magelang city explicitly declares the notion of a smart city in its official policy document. Whilst Yogyakarta, Surabaya, and Madiun city do not explicitly state the smart city definition in their official development planning document. This study has also determined that there is no clarity on smart city definition although it is very important to have a clear definition for future policy agendas.

Definition matters in order to address the following issues. Firstly, the clarity of the concept provides stakeholders with a robust understanding about the clarity of government policies and programs so that it can answer what, who, when, how, and how far the smart city program is implemented. Secondly, it enables set standards which can be used as a reference to monitor and evaluate the smart city program. Thirdly, in the theoretical perspective, clarity of terminology helps researchers to make policy theorization of the smart city conception.

This study has some limitations that need to be noted. Firstly, the use of policy text as the main source of data will lead to narrow perspectives on smart city definition and conceptualisation. Secondly, some the official regional development planning document/RPJMD of these cities were legalised before the city administrations declared a smart city initiative (e.g. Yogyakarta city). Future research may emphasize multiple data sources, not only from policy text but also from interviews and focus group discussions by policy makers, councils, major, and local government apparatus to gain more in-depth information about smart city-related policy research.

\section{Acknowledgement}

The first version of this manuscript was presented at The International Conference on Public Policy 28-30 June 2017 in Singapore. Smart City in Asia Panel 


\section{REFERENCES}

1. Albino, V., Berardi, U. \& Dangelico, R. M. (2015). Smart Cities: Definitions, Dimensions, Performance, and Initiatives. Journal of Urban Technology, 22(February), pp. 3-21. Available at: DOI: 10.1080/10630732.2014.942092 (accessed: 30 August, 2018).

2. $\quad$ Alejandro, S.-M., Arturo, H.-R., Carmen, C.-P., Bayod, E., Lugaric, L., Krajcar, S., Simic, Z., Santis, R. De, Fasano, A., Mignolli, N. \& Villa, A. (2014). Public Administration and Information Technology, IEEE PES Innovative Smart Grid Technologies Conference Europe, ISGT Europe. Available at: DOI: 10.1108/TG-03-2014-0010 (accessed: 30 August, 2018).

3. Angelidou, M. (2014). Smart City Policies: A Spatial Approach. Cities. Elsevier Ltd, 41, pp. S3-S11. Available at: DOI: 10.1016/j.cities.2014.06.007 (accessed: 30 August, 2018).

4. Anthopoulos, L. \& Fitsilis, P. (2010). From Digital to Ubiquitous Cities: Defining a Common Architecture for Urban Development. Proceedings - 2010 6th International Conference on Intelligent Environments, IE 2010, pp. 301-306. Available at: DOI: 10.1109/IE.2010.61 (accessed: 30 August, 2018).

5. Anthopoulos, L.G. \& Reddick, C.G. (2016). Smart City and Smart Government: Synonymous or Complementary? Proceedings of the 25th International Conference Companion on World Wide Web, pp. 351-355. Available at: DOI: 10.1145/2872518.2888615 (accessed: 30 August, 2018).

6. Caragliu, A., Del Bo, C. \& Nijkamp, P. (2011). Smart Cities in Europe. Journal of Urban Technology, vol. 18, no 2, pp. 65-82. Available at: DOI: 10.1080/10630732.2011.601117 (accessed: 30 August, 2018).

7. Carter, N., Ladrech, R., Little, C. \& Tsagkroni, V. (2017). Political Parties and Climate Policy: A New Approach to Measuring Parties' Climate Policy Preferences. Party Politics, (February). Available at: DOI: 10.1177/1354068817697630 (accessed: 30 August, 2018).

8. Chourabi, H., Nam, T., Walker, S., Gil-Garcia, J. R., Mellouli, S., Nahon, K., Pardo, T. A. \& Scholl, H. J. (2011). Understanding Smart Cities: An Integrative Framework. Proceedings of the Annual Hawaii International Conference on System Sciences, pp. 2289-2297. Available at: DOI: 10.1109/HICSS.2012.615 (accessed: 30 August, 2018).

9. Dameri, R.P. (2013). Searching for Smart City Definition: A Comprehensive Proposal. International Journal of Computers \& Technology, vol. 11, no 5, pp. 2544-2551. Available at: DOI: 10.1007/s13132-012-0084-9 (accessed: 30 August, 2018).

10. Dameri, R.P. \& Cocchia, A. (2013). Smart City and Digital City: Twenty Years of Terminology Evolution. X Conference of the Italian Chapter of AIS, ITAIS 2013, pp. 1-8.

11. Van Eeten, M.J.G. (2007). Narrative Policy Analysis. Handbook of Public Policy Analysis: Theory, Politics, and Methods, pp. 251-271. Available at: DOI: 10.4135/9781848608054 (accessed: 30 August, 2018).

12. Van Eeten, M.J.G., Loucks, D.P. \& Roe, E. (2002). Bringing Actors Together around LargeScale Water Systems: Participatory Modelling and Other Innovations. Knowledge, Technology \& Policy, vol. 14, no 4, pp. 94-108. Available at: DOI: 10.1007/s12130-002-1017-x (accessed: 30 August, 2018).

13. Eeten, M. Van and Roe, E. (2000). When Fiction Conveys Truth and Authority. Journal of the American Planning Association, vol. 66, no 1, pp. 58-67. Available at: DOI: 10.1080/ 01944360008976084 (accessed: 30 August, 2018). 
14. Giffinger, R. et al. (2007). Smart Cities - Ranking of European Medium-Sized Cities. October. Available at: http://www.smart-cities.eu/download/smart_cities_final_report.pdf (accessed: 30 August, 2018).

15. Giffinger, R. \& Fertner, C. (2007). City-Ranking of European Medium-Sized Cities. Centre of Regional Science, Vienna UT, pp. 1-12.

16. Gil-Garcia, J. R., Pardo, T. A. \& Nam, T. (2015). What Makes a City Smart? Identifying Core Components and Proposing an Integrative and Comprehensive Conceptualization. Information Polity, vol. 20, no 1, pp. 61-87. Available at: DOI: 10.3233/IP-150354 (accessed: $30 \mathrm{Au}-$ gust, 2018).

17. Harrison, C. \& Donnelly, I.A. (2011). A Theory of Smart Cities. Proceedings of the 55th Annual Meeting of the ISSS - 2011, Hull, UK, pp. 1-15. Available at: DOI: 10.1017/ CBO9781107415324.004 (accessed: 30 August, 2018).

18. Howlett, M. (2011). Designing Public Policies, Principles and Instruments. New York: Roudledge.

19. Kim, T.-Hoon, Ramos, C. \& Mohammed, S. (2017). Smart City \& IoT. Future Generation Computer Systems. Elsevier B.V., no 76 (July 2014), pp. 159-162. Available at: DOI: 10.1016/j. future.2017.03.034 (accessed: 30 August, 2018).

20. Klijn, E. \& Koppenjan, J. (2012). Governance Network Theory: Past, Present and Future. Policy and Politics, vol. 40, no 4, pp. 587-606.

21. Komninos, N. (2006). Integrating Human, Collective, and Artificial Intelligence to Enhance Knowledge and Innovation. Nicos Komninos 2nd International Conference on Intelligent Environments, Institution of Engineering and Technology, Athens, 5-6 July, pp. 13-20.

22. Krippendorff, K. (2013) Content Analysis: An Introduction to Its Methodology. Beverly Hills: SAGE publication.

23. Luna-Reyes, L.F., Mellouli, S. \& Bertot, J.C. (2013). Key Factors and Processes for Digital Government Success. Information Polity, vol. 18, no 2, pp. 101-105. Available at: DOI: 10.3233/IP-130307 (accessed: 30 August, 2018).

24. Mayangsari, L. \& Novani, S. (2015). Multi-Stakeholder Co-Creation Analysis in Smart City Management: An Experience from Bandung, Indonesia. Procedia Manufacturing. Elsevier B.V., no 4 (Iess), pp. 315-321. Available at: DOI: 10.1016/j.promfg.2015.11.046 (accessed: 30 August, 2018).

25. Meijer, A. \& Bolívar, M.P.R. (2016). Governing the Smart City: A Review of the Literature on Smart Urban Governance. Available at: DOI: 10.1177/0020852314564308 (accessed: 30 August, 2018).

26. Menon, A. (2017). Smart Cities, Livable Cities. GfK Marketing Intelligence Review, vol. 9, no 1, pp. 48-52. Available at: https://search.proquest.com/docview/1917345086? accountid=13 607\%0Ahttp://e-tidsskrifter.kb.dk/resolve??url_ver=Z39.88-2004\&rft_val_fmt=info:ofi/fmt: kev:mtx:journal\&genre=article\&sid=ProQ:ProQ\%3Asocialsciencepremium\&atitle=Smart+ Cities\%2C+Livable+Cities\&tit (accessed: 30 August, 2018).

27. Mulay, S.A., Dhekne, C.S., Bapat, R.M., Budukh, T.U. \& Gadgil, S.D. (2011). Intelligent City Traffic Management and Public Transportation System, pp. 1-5.

28. Nam, T. \& Pardo, T.A. (2011). Conceptualizing Smart City with Dimensions of Technology, People, and Institutions. Proceedings of the 12th Annual International Digital Government Research Conference on Digital Government Innovation in Challenging Times - dg.o '11, p. 282. Available at: DOI: 10.1145/2037556.2037602 (accessed: 30 August, 2018). 
29. Neirotti, P., De Marco, A., Cagliano, A.C., Mangano, G. \& Scorrano, F. (2014) Current Trends in Smart City Initiatives: Some Stylised Facts, Cities. Available at: DOI: 10.1016/ j.cities.2013.12.010 (accessed: 30 August, 2018).

30. Öberg, C., Graham, G. \& Hennelly, P. (2017). Smart Cities - A Literature Review and Business Network Approach Discussion on the Management of Organisations. IMP Journal. Available at: DOI: 10.1108/IMP-06-2015-0024 (accessed: 30 August, 2018).

31. Paroutis, S., Bennett, M. \& Heracleous, L. (2014). A Strategic View on Smart City Technology: The Case of IBM Smarter Cities During a Recession. Technological Forecasting and Social Change. Elsevier Inc., 89 (October 2013), pp. 262-272. Available at: DOI: 10.1016/j. techfore.2013.08.041 (accessed: 30 August, 2018).

32. Parsons, W. (1995). Public Policy: An Introduction to the Theory and Practice of Policy Analysis. UK: Edward Elgar Publishing.

33. Piro, G., Cianci, I., Grieco, L.A., Boggia, G. \& Camarda, P. (2014). Information Centric Services in Smart Cities. Journal of Systems and Software, vol. 88, no 1, pp. 169-188. Available at: DOI: 10.1016/j.jss.2013.10.029 (accessed: 30 August, 2018).

34. Rachmawati, T. (2017). Smart Environment Program, Smart Way to Smart City. Policy \& Governance Review, vol. 1, no 1, pp. 26-36.

35. Rahmat, A., Syadiah, N. \& Subur, B. (2016). Smart Coastal City: Sea Pollution Awareness for People in Surabaya Waterfront City. Procedia - Social and Behavioral Sciences, vol. 227, 14 July, pp. 770-777. Available at: DOI: 10.1016/j.sbspro.2016.06.144 (accessed: 30 August, 2018).

36. Rezende, D.A., Madeira, G.D S., Mendes, L.D.S., Breda, G.D., Zarpelão, B.B. \& Figueiredo, F.D.C. (2014). Information and Telecommunications Project for a Digital City: A Brazilian Case Study. Telematics and Informatics. Elsevier Ltd, vol. 31, no 1, pp. 98-114. Available at: DOI: 10.1016/j.tele.2013.05.001 (accessed: 30 August, 2018).

37. Roe, E. (1994). Narrative Policy Analysis: Theory and Practice. 1999. Available at: DOI: 10.1017/CBO9781107415324.004 (accessed: 30 August, 2018).

38. Rusadi, E.Y., Nurhayati, P., Tallo, A.J. \& Setiawan, B. (2016). Smart Green Open Space Outlook: Pattern Identification (Case Study: Yogyakarta City and Batu City). Procedia - Social and Behavioral Sciences, vol. 227, pp. 630-636. Available at: DOI: 10.1016/j.sbspro.2016.06.125 (accessed: 30 August, 2018).

39. Sasono, M.E.N., Purwitaningsih, S., Yusuf, L. \& Navastara, A.M. (2016). Surabaya Smart Subway Development as an Alternative Mode in Ahmad Yani Corridor Surabaya by TOD Concept Application. Procedia - Social and Behavioral Sciences, vol. 227, pp. 132-138. Available at: DOI: 10.1016/j.sbspro.2016.06.053 (accessed: 30 August, 2018).

40. Shanahan, E.A., Mcbeth, M.K. \& Hathaway, P.L. (2011). Narrative Policy Framework: The Influence of Media Policy Narratives on Public Opinion. Politics and Policy, vol. 39, no 3, pp. 373-400. Available at: DOI: 10.1111/j.1747-1346.2011.00295.x (accessed: 30 August, 2018).

41. Snow, C.C., Håkonsson, D.D. \& Obel, B. (2016). A smart City is a Collaborative Community: Lessons from Smart Aarhus. California Management Review, vol. 59, no 1, pp. 92-108. Available at: DOI: 10.1177/0008125616683954 (accessed: 30 August, 2018).

42. Suakanto, S., Supangkat, S.H., Suhardi \& Saragih, R. (2013). Smart City Dashboard for Integrating Various Data of Sensor Networks. Proceedings - International Conference on ICT for Smart Society 2013: "Think Ecosystem Act Convergence", ICISS 2013, pp. 52-56. Available at: DOI: 10.1109/ICTSS.2013.6588063 (accessed: 30 August, 2018). 
43. Suhendra, A. (2017). Kesiapan Pemerintah Daerah dalam Mewujudkan Kota Cerdas di Bandung dan Surabaya. Matra Pembaruan, vol. 1, no 1, pp. 1-9.

44. Suryotrisongko, H., Kusuma, R.C. \& Ginardi, R.H. (2017). Four-Hospitality: Friendly Smart City Design for Disability. Procedia Computer Science. Elsevier B.V., no 124, pp. 615-623. Available at: DOI: 10.1016/j.procs.2017.12.197 (accessed: 30 August, 2018).

45. Susanti, R., Soetomo, S., Buchori, I. \& Brotosunaryo, P.M. (2016). Smart Growth, Smart City and Density: In Search of the Appropriate Indicator for Residential Density in Indonesia. Procedia - Social and Behavioral Sciences. Elsevier B.V., no 227 (November 2015), pp. 194-201. Available at: DOI: 10.1016/j.sbspro.2016.06.062 (accessed: 30 August, 2018).

46. Sutanta, H., Aditya, T. \& Astrini, R. (2016). Smart City and Geospatial Information Availability, Current Status in Indonesian Cities. Procedia - Social and Behavioral Sciences. Elsevier B.V., vol. 227 (November 2015), pp. 265-269. Available at: DOI: 10.1016/ j.sbspro.2016.06.070 (accessed: 30 August, 2018).

47. Tarigan, A.K.M., Sagala, S., Samsura, D.A.A., Fiisabiilillah, D.F., Simarmata, H.A. \& Nababan, M. (2016). Bandung City, Indonesia. Cities. Elsevier B.V., no 50 (February), pp. 100-110. Available at: DOI: 10.1016/j.cities.2015.09.005 (accessed: 30 August, 2018).

48. Will, L., Benoit, K., Slava, M. \& Laver, M. (2011). Scaling Policy Preferences from Coded Political Texts. Legislative Studies Quarterly, vol. 36, no 1, pp. 123-155. Available at: DOI: 10.1111/j.1939-9162.2010.00006.x (accessed: 30 August, 2018).

49. Wiseli, D., Tanusetiawan, R. \& Purnomo, F. (2017). Simulation Game as a Reference to Smart City Management. Procedia Computer Science. Elsevier B.V., no 116, pp. 468-475. Available at: DOI: 10.1016/j.procs.2017.10.053 (accessed: 30 August, 2018).

50. Wolfe, M., Jones, B. D. \& Baumgartner, F.R. (2013). A Failure to Communicate: Agenda Setting in Media and Policy Studies. Political Communication, no 30 (May 2013), pp. 175-192. Available at: DOI: 10.1080/10584609.2012.737419 (accessed: 30 August, 2018). 